HISTORIA: Jurnal Pendidik dan Peneliti Sejarah, 3(2), 103-112. DOI: https://doi.org/10.17509/historia.v3i2.21607.

JURNAL UPI

\title{
MENELUSURI SEJARAH LISAN DI JAWA BARAT: SEBUAH LANGKAH AWAL DALAM UPAYA MENYELAMATKAN SUMBER SEJARAH
}

\author{
Yeni Kurniawati, Murdiyah Winarti, Wawan Darmawan \\ Departemen Pendidikan Sejarah, \\ Fakultas Pendidikan Ilmu Pengetahuan Sosial, Universitas Pendidikan Indonesia (UPI) \\ yenikurniawati@upi.edu
}

To cite this article: Kurniawati, Y., Winarti, M., \& Darmawan, W. (2020). Menelusuri sejarah lisan di Jawa Barat: sebuah langkah awal dalam upaya menyelamatkan sumber sejarah. HISTORIA: Jurnal Pendidik dan Peneliti Sejarah, 3(2), $103-112$. https://doi.org/10.17509/historia.v3i2.21607.

Naskah diterima : 3 Desember 2019, Naskah direvisi : 11 Mei 2020, Naskah disetujui : 20 Mei 2020

\begin{abstract}
The tracing of oral history in West Java is the research's result to obtain some information about the witnesses' experiences and historical actors from various circles. Oral history has its significance when written documents remain scarce or extinct. There where a lot of information regarding the past still scattered or missed from the record, while the lifespan of the resources limited. However oral history will enrich: research methods, history sources (oral), and enrich the history writing substantively. Can be used as a source for anyone who wants to do historical research, and in general for science development. Oral history which managed properly will provide unlimited information in numbers/pages, often even giving rise to information that has not been written. This becomes the main concern as well as an initial step for the History Education Department Universitas Pendidikan Indonesia to carry out the writing and to gather collective memory as an effort to save these historical sources. The disappearing of oral historical sources in one generation means a great loss in historical writing.
\end{abstract}

Keyword: collective memory; historical sources; oral history; west java.

\begin{abstract}
Abstrak
Menelusuri sejarah lisan di Jawa Barat ini merupakan hasil penelitian untuk mendapatkan sejumlah informasi tentang pengalaman para saksi dan pelaku sejarah dari berbagai kalangan. Sejarah lisan memiliki arti penting manakala dukumen tertulis sangat terbatas atau tidak ada sama sekali. Ada banyak informasi tentang masa lalu masih tercecer atau lolos dari pencatatan, sementara itu usia hidup dari para narasumber terbatas. Bagaimanapun juga sejarah lisan akan memperkaya: metode penelitian, sumber sejarah (lisan), memperkaya penulisan sejarah secara substantif, dapat dipergunakan sebagai sumber bagi siapapun yang hendak melakukan penelitian sejarah, dan pada umumnya untuk pengembangan ilmu pengetahuan. Sejarah lisan yang ditangani dengan baik akan memberikan informasi yang tidak terbatas dalam jumlah/ halaman, bahkan sering memunculkan informasi yang belum termuat secara tertulis. Hal inilah yang menjadi kepedulian dan juga merupakan langkah awal bagi Departemen Pendidikan Sejarah UPI untuk melakukan penulisan dan pengumpulan memori kolektif sebagai upaya menyelamatkan sumber sejarah tersebut. Hilangnya sumber sejarah lisan dalam satu generasi merupakan kerugian yang besar dalam penulisan sejarah.
\end{abstract}

Kata Kunci: Jawa Barat; memori kolektif; sejarah lisan; sumber sejarah; veteran perang. 


\section{PENDAHULUAN}

Sejarah pada hakekatnya adalah ilmu tentang manusia mengkaji kerja keras manusia mencapai keinginannya, kisah tentang apa yang telah dilakukan manusia, apa yang mereka tinggalkan bagi generasi penerus, sumbangan peradaban yang membawa kemajuan baik moral maupun material (Kochhar, 2008). Untuk merekonstruksi kembali ceritera tentang masala lalu tersebut diperlukan berbagai data dan fakta yang tersimpan dalam berbagai sumber sejarah.

Dalam studi sejarah dikenal adanya klasifikasi sumber berdasarkan urutan waktunya yang meliputi: sumber lisan (tradisi lisan dan sejarah lisan), sumber benda, serta sumber tertulis (sering disebut dokumen). Dipelopori oleh Leopold von Ranke yang hidup pada abad ke 19, penekanan penggunaan dokumen (arsip) tertulis dalam studi sejarah telah dimulai. Tidak ada dokumen, berarti tidak ada sejarah (no document - no history) merupakan ungkapan yang memposisikan tertulis/ dokumen sebagai sumber sejarah yang dianggap paling penting (Priyadi, 2017).

Dengan kata lain, seorang peneliti sejarah dipastikan akan mengalami kesulitan bila tidak didukung oleh sumber tertulis yang beragam wujudnya (buku/ naskah, arsip, memoir, catatan harian dll). Salah satu karakteristik yang melekat dalam sumber tertulis/ dokumen adalah esensi dari informasi yang berupa tulisan, dapat dibaca dengan mudah, dan tidak berubah meskipun berasal dari masa lampau yang sangat jauh.

Sementara ketiadaan atau keterbatas sumber tersebut bisa dilengkapi dengan sumber benda atau sumber lisan, baik tradisi lisan maupun sejarah lisan. Terlebih bila menyangkut peristiwa yang berlangsung di tingkat lokal, sering kesulitan menemukan sumber sejarah berupa dokumen, sehingga perlu didukung sumber benda (bila dimungkinkan), sumber lisan berupa sejarah lisan, dan untuk hal-hal tertentu bahkan tradisi lisan.

Penelitian ini merupakan awal dari penelitian Departemen Pendidikan Sejarah dalam upaya mengumpulkan sumber sejarah lisan untuk disimpan di laboratorium dan digunakan serta dimanfaatkan oleh mahasiswa ataupun peneliti lainnya sebagai sumber penelitian sejarah. Suatu bentuk kepedulian dari departemen untuk melakukan inventarisasi atau pendokumentasian sumber lisan. Dimulai dengan mengembangkan penelitian sejarah lisan terhadap para narasumber (pelaku maupun saksi) yang pernah ikut secara langsung atau tidak lansung, bahkan terhadap saksi tentang perjuangan mereka yang kami sebut veteran, yang dahulunya berjuang mempertahankan NKRI. Apa yang hendak dicapai atau menjadi target dari pengembangan sejarah lisan melalui penulisan dan inventarisasi memori kolektif adalah pengembangan sumber sejarah non-tulisan/ lisan untuk kepentingan penelitian dan pengembangan ilmu pengetahuan pada umumnya.

Bagi Departemen Pendidikan Sejarah penelitian ini diharapkan akan melengkapi koleksi laboratorium/ perpustakaan yang sudah dimiliki departeman. Jadi, selain memiliki sejumlah sumber tertulis berupa bukubuku, nantinya juga akan dilengkapi dengan sumber lisan yang disimpan dalam pita kaset/CD, serta transkrip wawancara sebagi hasil dari penelitian ini. Hilangnya sumber sejarah lisan dalam satu generasi merupakan kerugian yang besar dalam penulisan sejarah. Meskipun sejarah lisan kerap di nomerduakan, karena informasi secara lisan yang keluar dari mulut nara sumber sering kurang dipercaya (Priyadi, 2017). Bahwa selama ini hasil penelitian yang dilakukan oleh para peneliti terutama penulisan/ transkrip dan produknya berupa rekaman kaset/ CD, ada yang tersimpan di Arsip Nasional, dan kemungkinan lebih banyak lagi tersimpan di berbagai tempat, atau tersimpan di masing-masing peneliti.

Intinya sudah ada penelitian yang berhubungan dengan pengembangan sejarah lisan, tetapi hasilnya belum tersosialisasi dengan optimal, sehingga menyulitkan bila ada yang ingin mencarinya. Berkaitan dengan hal itu semua, Departemen Pendidikan Sejarah tidak berkecil hati, bila digarap dengan baik sejarah lisan akan banyak manfaatnya. Oleh sebab itu, Departemen berharap bisa berpartisipasi aktif dalam upaya menuliskan transkrip dan mendokumentasikan informasi dari para saksi sejarah. Dengan demikian secara tidak langsung Departemen Pendidikan Sejarah akan melengkapi dan melestarikan informasi lisan melalui kegiatan penelitian ini.

Riset-riset sejarah lisan digunakan untuk mengekplorasi sejarah yang tidak banyak meninggalkan dokumen tertulis atau juga untuk mengungkap hal-hal yang tidak terekam dalam dokumen. Sejarah lisan dapat menanamkan rasa kemanusiaan pada materi sejarah yang agak kering serta memberikan tekstur dan wawasan yang kaya di atas apa yang bisa dipelajari dari bahan arsip (Aharon, 2020). Sejarah lisan memungkinkan kita untuk mengeksplorasi berbagai pertanyaan penelitian yang lebih luas berdasarkan identitas, budaya, makna, dan narasi (Hammond, 2015).Sejarah lisan digunakan sebagai metode mandiri tanpa adanya sumber lain yang layak, terutama bagi mereka yang menginginkan pemahaman yang lebih dalam tentang asal-usul kebijakan dan perubahannya dari waktu ke waktu (Aharon, 2020). 
HISTORIA: Jurnal Pendidik dan Peneliti Sejarah, 3(2), 103-112. DOI: https://doi.org/10.17509/historia.v3i2.21607.

Sejarah lisan berusaha untuk mencerminkan sudut pandang dari mana kesaksian tersebut dibuat. Artinya, ini memungkinkan kelompok-kelompok nonhegemonik untuk berbicara bagi diri mereka sendiri dan dengan cara ini, sejarah lisan dapat memiliki efek politik: menantang pandangan konvensional dan lebih ilmiah tentang sejarah (Harding \& Gabriel, 2004).

Dengan demikian, beberapa sejarawan kadangkadang menggunakan sejarah lisan sebagai sumber empiris tambahan untuk melengkapi catatan resmi resmi yang seringkali merupakan sumber utama utama dari pekerjaan mereka; mereka melakukan itu untuk menawarkan perspektif yang berbeda tentang atau lebih banyak wawasan bernuansa ke dalam kebijakan luar negeri dari bawah ke atas yang menanamkan rasa kemanusiaan pada bahan sejarah yang agak kering (Aharon, 2020). Penelitian sejarah lisan dalam hal tujuannya 'memberikan suara' kepada kelompokkelompok yang terpinggirkan dan penulisan 'sejarah dari bawah', yang menyoroti pengalaman subjektif biasa sehari-hari (Harding \& Gabriel, 2004). Para sejarawan memang menilai, ada beberapa kekurangan dari penggunaan sejarah lisan sebagai sumber sejarah, yaitu keakuratan kisah narator hanya berdasarkan ingatan mereka dan skeptis terhadap keterampilan mewawancarai sejarawan, sehingga membuat sejarah lisan yang telah dilakukan juga tidak dapat diandalkan sebagai sumber utama (Aharon, 2020).

Sejarawan Amerika dan Israel mulai bekerjasama untuk mengeksplorasi potensi sejarah lisan dalam pekerjaan mereka. James Blight dan Janet Lang, melakukan pengkajian studi kasus tentang bagaimana sejarah lisan dapat menjadi metode yang berguna untuk memeriksa momen yang disengketakan dalam sejarah diplomatik akhir Perang Dingin (Aharon, 2020). Andrew Hammond (sejarawan Skotlandia), juga telah mengeksplorasi peran Badan Intelijen Pusat AS (selanjutnya CIA) dalam kebijakan luar negeri AS (Hammond, 2015). Sementara itu, Clila Magen dan Eytan Gilboa meneliti dampak dan kelebihan sejarah lisan dari sumber petugas intelijen Israel. Mereka menyelidiki hubungan timbal balik antara ISA dan media lokal. Ketika mereka mencatat, "Wawancara menghasilkan informasi yang sangat berharga yang tidak ditemukan di sumber lain. Wacana yang biasanya tetap ada di balik layar dalam komunitas intelijen dimunculkan ke depan (Aharon, 2020).

Di Australia, proyek sejarah lisan Australia sudah dimulai sejak 1938, yang dimulai pada akhir 1970an untuk peringatan dua abad penjajahan Eropa, dan terdiri hanya di bawah 600 rekaman dengan beragam warga Australia yang lahir antara tahun 1890-an dan awal 1930-an (Holmes dkk, 2016). Koleksi sejarah lisan Perpustakaan Nasional sebagian besar terdiri dari wawancara dengan Elit politik, budaya, atau profesional Australia, atau tentang topik-topik tertentu yang memiliki kepentingan nasional seperti proyek Stolen Generations, dan perpustakaan tertarik untuk mendukung proyek wawancara sejarah sosial yang akan melengkapi koleksi Australia 1938 dengan merekam kisah kehidupan non-elit Warga Australia lahir sejak tahun 1920-an (Holmes dkk, 2016). Sebagian besar proyek sejarah lisan dikerjakan dengan mewawancarai orang-orang dari kelompok umur yang berbeda sehingga dapat mengeksplorasi perubahan sosial dan budaya sepanjang waktu dan membandingkan pengalaman kelompok kelahiran yang berbeda, seperti cara pria dan wanita yang lahir pada tahun 1930-an, 1950-an dan 1970-an menjadi orang tua atau merespons teknologi baru (Holmes dkk, 2016).

Eugneu Rogan (sejarawan Inggris) melakukan riset sejarah lisan di Palestina dan Israel. Gagasan proyek sejarah lisan terinspirasi oleh hadiah dua koleksi utama dokumen tentang Kepolisian Palestina, yang disimpan di Arsip Pusat Timur Tengah di St Antony's College, Oxford. Ini adalah koleksi besar, mengisi sekitar lima puluh kotak arsip (Rogan, 2007: hlm. 37).

\section{METODE PENELITIAN}

Dalam menelusuri sejarah lisan di Jawa Barat ini menggunakan metode sejarah lisan, dengan teknik wawancara. Wawancara adalah sebuah kegiatan yang dilaksanakan untuk menggali suatu informasi tertentu yang dibutuhkan dari salah seorang narasumber secara langsung (Aharon, 2020). Menggunakan metode sejarah lisan diharapkan dapat memperoleh informasi atau keterangan lisan tentang hal-hal yang belum tercatat dalam dokumen-dokumen, dan paling tidak akan menguatkan keterangan yang sudah ada sebelumnya. Wawancara merupakan suatu bagian yang penting dalam suatu proses pencarian berita atau informasi lisan. Ditinjau dari pelaksanaannya, digunakan teknik wawancara bebas terpimpin (kombinasi wawancara bebas dan terpimpin), yang dalam pelaksanaannya pewawancara sudah membawa sederet pertanyaan secara garis besar, sebagai pedoman tentang berbagai hal yang akan ditanyakan.

Yang berhasil dihimpun oleh pihak Departemen Pendidikan Sejarah UPI baru menelusuri sejarah lisan dari pihak tokoh lokal dari kalangan militer yang sekarang sering disebut dengan pejuang veteran. 
Sementara bisa ditemui adalah: 3 orang tokoh Jawa Barat, yang di wawancarai di LVRI yaitu Kolonel (Purn) Tatang Endang (94 tahun), Kolonel (Purn) Lili Somantri (93 tahun) dan Kolonel (Purn) Asep (92 tahun). Mereka terlibat langsung (pelaku) dalam peristiwa Bandung Lautan Api dengan porsi yang berbeda-beda. Kolonel (Purn) Tatang Endang dan Kolonel Lili Somantri saat itu termasuk ISLB (Ikatan Sekolah Lanjutan Bandung), GASEWA (Gabungan Sekolah Menengah, dan gabungan sekolah teknik dan Ikatan Pelajar Indonesia (IPI), di mana fokusnya memang menjadi pemuda pejuang ketika mereka mengenyam SMP. Beberapa pertempuran kecil di berbagai wilayah kota sebelum Bandung Lautan Api dilaluinya hingga proses bumi hangus atas sebagian wilayah Bandung. Begitupula dengan Kolonel (Purn) Asep, meskipun tidak menceritakan secara detail kondisi Bandung Lautan Api, karena lebih menekankan pada peristiwa Hijrah dan Long March.

Untuk wawancara dilakukan secara simultan, dengan menghadirkan ke tiga narasumber secara bersamaan dalam satu ruangan. Cara seperti di diperbolehkan dalam malakukan proses penelusuran sumber lisan, selain dirasa efisien dari unsur waktu dan biaya, juga secara langsung saling mengingat kembali / cros cek informasi atas peristiwa yang pernah dialami dan dilihat dahulu (Holmes dkk, 2016). Memang ada cara lain yaitu face to face, saling bertemu satu persatu setiap narasumber /saksi sejarah dengan peneliti disuatu tempat yang telah disepakati sebelumnya. Hal ini bisa dilakukan bila mana peneliti akan menggali informasi secara mendalam dan meluas, butuh waktu yang lebih longgar tentunya (Hammond, 2015).

\section{PEMBAHASAN}

\section{Menggali Jejak-Jejak Sejarah Lisan di Jawa Barat}

Dalam studi sejarah dikenal beberapa klasifikasi sumber sejarah yang berisi berbagai informasi tentang masa lampau. Informasi tersebut dapat dimuat dalam berbagai macam cara yaitu: tulisan (dukumen), gambar, lukisan, foto, relief, dll (pictorial), maupun lisan (oral) (Sjamsuddin, 2012). Di Indonesia keberadaan sumber tertulis relatif belum optimal, salah satunya dikarenakan budaya menulis belum merupakan kebiasaan yang dianggap penting. Peristiwa-peristiwa yang pernah terjadi dilingkungan sekitar sebagian besar masih tersimpan dalam memori atau ingatan orang per orang. Mengutamakan sumber tertulis dalam penulisan sejarah sebenarnya merupakan hal yang biasa. Menyadari adanya kelangkaan sumber tertulis maka perlu digalakkan pengumpulan informasi lisan melalui kegiatan sejarah lisan. Sebagaimana dikatakan oleh Kuntowijoyo, bahwa sejarah lisan tidak kurang pentingnya bila dilakukan secara cermat (Kuntowijoyo, 2003). Paling tidak ini terbukti dalam tulisan akadamik (sekripsi) mahasiswa S1 Pendidikan Sejarah UPI, ketika menggali sejarah lokal sangat tergantung pada sumber lisan, khususnya sejarah lisan (Arsip Departemen Pendidikan Sejarah UPI 2010-2019). Tosh mengatakan bahwa sejak tahun 1960-an sejarah lisan banyak digunakan di Inggris dan negara-negara Barat lainnya, terutama untuk menyusun sejarah sosial (Sjamsuddin, 2012).

Adapun yang dimaksud sejarah lisan adalah ingatan tangan pertama yang dituturkan secara lisan oleh para nara sumber yang diwawancarai peneliti (ANRI, 1981). Keunggulan sumber sejarah lisan dibandingkan dengan sumber-sumber sejarah lain yang tidak lebih sebagai benda mati adalah karena berkedudukan sebagai makhluk bernyawa, yang memiliki kesadaran dan pemikiran, yang masing-masing memiliki karakter (Priyadi, 2017). Dalam hal sejarah lisan ada upaya penumpulan data informasi tentang masa lampau yang diperoleh dengan melalui wawancara.

Sejak abad 20 sejarah lisan memperoleh kembali kekuatannya setelah adanya teknologi baru dalam perekaman suara dengan munculnya pita kaset/ tape rekaman (Kuntowijoyo, 2003). Seiring dengan kemajuan teknologi tersebut, sejarah lisan mengalami kemajuan, dimana sekarang orang tidak harus saling bertemu untuk melakukan komunikasi, termasuk hubungan melalui surat-menyurat semakin berkurang (ANRI, 2018). Dengan demikian banyak data yang diperlukan tidak lagi dapat diketemukan dalam bentuk tertulis, oleh sebab itu adanya upaya penelusuran sejarah lisan diharapkan menjadi salah satu cara untuk mengatasi hilangnya data-data lisan yang sangat berharga dalam penulisan sejarah.

Di era otonomi seperti sekarang ini, kesempatan untuk menelusuri pelaku dan saksi sejarah sangat terbuka. Memberikan pada daerah untuk secara maksimal mengembangkan penelitian guna menjawab dan menjelaskan pertanyaan-pertanyaan yang menyangkut masa lalu dari masyarakat yang bersangkutan. Meskipun menulis sejarah lokal adalah hak siapa saja dan dapat ditulis kapan saja, namun tampaknya perhatian dari pemerintah daerah sangat ditunggu. Kewenangan yang dimiliki pemerintah dapat menjembatani kerjasama anatara berbagai pihak seperti pendidik, museum, perguruan tinggi maupun pencinta sejarah lokal (Sejarah Lokal Diletantis).

Kenyataannya kesempatan ini tidak/ belum dimanfaatkan secara optimal, sehingga penulisan sejarah 
HISTORIA: Jurnal Pendidik dan Peneliti Sejarah, 3(2), 103-112. DOI: https://doi.org/10.17509/historia.v3i2.21607.

lokal belum mengalami perkembangan yang signifikan. Meskipun sebenarnya hal ini juga sangat berkaitan erat kepada persoalan sumber-sumber sejarah yang tersedia, khususnya sumber tertulis. Terbatasnya sumber tertulis merupakan salah satu faktor yang menjadikan sejarah lokal belum berkembang dengan baik. Sebagian besar sumber yang tersedia adalah sumber lisan baik itu tradisi lisan (oral tradition) maupun sejarah lisan (oral history). Sumber tertulis mengenai masa lalu suatu komunitas masyarakat di tempat/ lokalitas tertentu sangat terbatas, bahkan mungkin sumber lisan berupa tradisi lisan adalah satu-satunya akses untuk mendapatkan informasi tersebut. Bertolak dari hal ini melalui kewenangan yang dimiliki pemerintah daerah (era otonomi), diharapkan akan mampu menghimpun banyak informasi mengenai realitas masa lampau lingkungannya dengan mengumpulkan cerita-cerita lisan yang tersebar dari mulut ke mulut maupun melakukan wawancara dengan para saksi sejarah yang masih hidup.

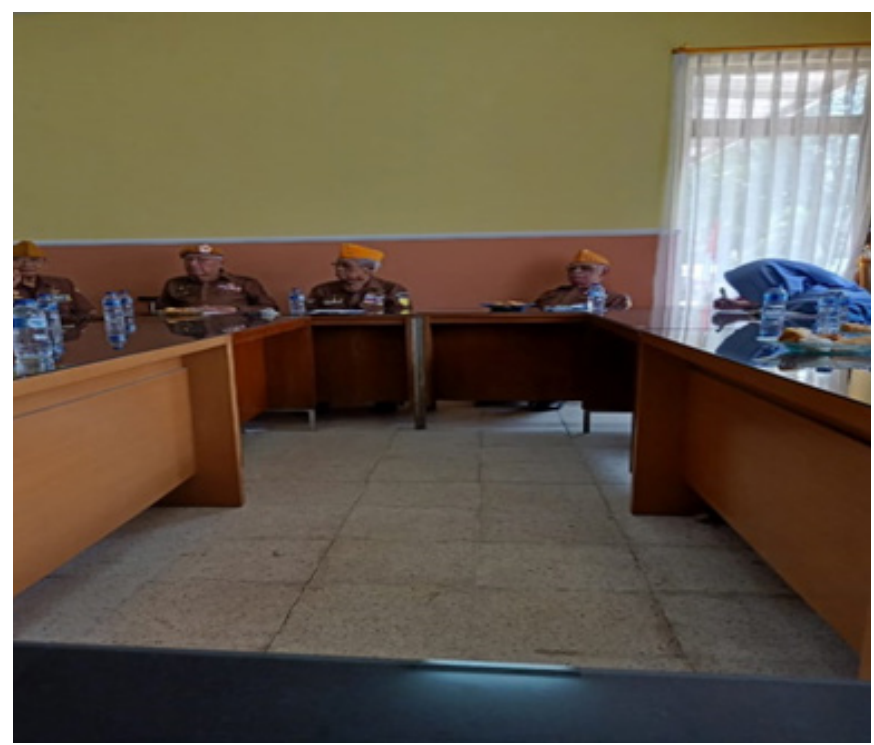

Gambar 4.1 Susasana Wawancara dengan Para Veteran Perang Kemerdekaan

Untuk menggali sejarah lisan tentunya harus berhadapan dengan saksi sejarah, bisa menyangkut pelaku ataupun saksi sejarah, sering dikategorikan ke dalam sumber pertama (Garaghan, 1957). Yang dimaksud pelaku dalam sejarah lisan bisa pelaku pemikir, karena dalam proses terjadinya peristiwa tidak lepas dari pemikiran seseorang yang mungkin berpengaruh; pelaku pelaksana; ataupun pelaku pengikut, yang biasanya berasal dari orang kebanyakan (orang kecil). Sesungguhnya seorang pelaku sejarah dapat pula berkedudukan sebagai saksi karena dirinya bisa menuturkan kesaksian bagi pelaku-pelaku yang lain. Atau para pelaku saling berkesaksian terhadap pelaku yang satu dengan pelaku yang lain. Pada intinya, kesaksian seorang pelaku adalah penyaksi bagi pelaku lain sehingga kesaksian yang dikolektifkan itu akan memberi kesaksian yang bulat dan saling mengisi sehingga peristiwa sejarah itu akan lebih jelas (Priyadi, 2017). Sementara saksi di sini adalah mereka, para narasumber yang terlibat langsung dan melihat sendiri peristiwa yang dimaksud dari para veteran yang ada di Jawa barat, khususnya berkedudukan di Kota Bandung. Mereka para saksi termasuk dalam kelompok tokoh lokal dari Jawa Barat yang ikut berjuang dalam menegakkan kedaulatan Indonesia pada masanya.

Keterangan lisan yang direkam ini merupakan salah satu bentuk dari sumber non-tertulis dan dimaksudkan untuk menjadi pelengkap bagi sumber tertulis, sebagai sumber yang amat penting dalam penulisan sejarah (ANRI, 2018). Perlu segera dilakukan upaya penelusuran, pencarian, dan selanjutnya melakukan wawancara, serta mentranskrip hasil wawancara tersebut sebagai wujud dari dokumentasi atas sumber sejarah lisan. Apa yang dilakukan di atas sangat tergantung dengan waktu, yaitu usia dari narasumber yang keadaan hidupnya tidak bisa diprediksi oleh siapapun. Merupakan langkah strategis dalam hal menyimpan pengalaman seseorang di masa lalu yang tidak tergantung lagi kepada aktor usia.

Setiap hari, yang disebut narasumber itu makin berkurang, baik karena kehilangan kenang-kenangannya (terbatas memorinya karena usia) ataupun telah meninggal. Yang telah dan akan oleh Departemen Pendidikan Sejarah UPI dalam menelusuri sejarah lisan di Jawa Barat ini tidak termasuk keharusan menganalisa atau mengkaitkan sumber-sumber sejarah sebagimana biasa dilakukan ketika hendak merekonstruksi sejarah, hanya baru pada tahapan menggali informasi dari para narasumber melalui wawancara yang disimpan di pita kaset/ CD dan selanjutnya dibuatkan trankripnya. Dalam wawancara seorang peneliti perlu menggunakan alat perekam/ tape recorder, maupun jenis alat teknologi lainnya untuk melakukan wawancara.

Setelah terkumpul dalam pita kaset/ CD tahapan berikutnya adalah membuat transkrip, yang intinya kegiatannya berupa pengalihan bentuk lisan ke bentuk tulisan. Proses ini harus dilakukan dengan hati-hati, suara yang terdengar dalam alat rekam sering kurang jernih, perlu dilakukan berulang-ulang sambil melihat catatan untuk mendapatkan kepastian/ kejelasan siapa narasumber yang sedang diidentifikasi informasinya. Seperti yang dilakukan disini, karena ketiga narasumber memberikan informasi secara simultan atau bersamasama dalam satu ruangan, dituntut lebih ekstra dalam mendengarkan suara/ informasinya dari narasumbrer satu dengan yang lainnya. Berbeda bila wawancara 
dilakukan secara individual, masing-masing ditemui secara terpisah waktunya. Pembuatan transkripsi dimaksukan untuk mempermudah pengolahan hasil penggalian sejarah lisan, tentang suatu peristiwa dari para tokoh lokal Jawa Barat sebagai sumber sejarah diharapkan menjadi lebih mudah dan lebih cepat.

Contoh dari sebagaian transkrip wawancara tentang peristiwa Bandung Lautan Api bisa dilihat di bawah ini:

Team UPI: kedatangan kami untuk mencari keterangan tentang sejarah lokal yang melibatkan bapak bapak sekalian yang ada disini:

Pa Lili : Kami para orang tua, yang bahkan sudah kakek lah yaa, yang tentu mempunyai banyak pengalaman berbeda dengan team UPI, menjadi harapan kami para orang tua untuk bisa mempunyai bekal untuk bisa menjawab persoalan persoalan bangsa, secara tenaga pun kami sudah terbatas. Bapak pribadi sangat senang dan menyambut baik kedatanagannya kesini.

Team UPI : Baik untuk yang pertama ya pa akan dimulai dulu dari peristiwa Bandung Lautan Api. Jadi secara pemahaman kamidariliteraturbahwasanyaperistiwa Bandung Lautan Api ini bukan pertempuran ya pa, tapi lebih terhadap membumihanguskan Bandung dengan suatu kepentingan kedaulatan nasional

Pak Tatang: Agak sulit ya untuk dipahami nya

Team UPI : Jadi pa intinya kami ingin mengetahui peristiwa BLA ini secara pengalaman bapak langsung menjadi pelaku dari peristiwa tersebut, mungkin lebih lengkapnya pengen mengetahui kedudukan, status bapak pada saat itu

Pa Tatang : Hanya barangkali kalo saya harus memulai, yang saya ketahui tidak sedikit yang keliru dalam menafsirkan peristiwa BLA ini, jadi sebetulnya seperti apa yang kami alami ini, bahwa BLA ini tidak seperti pertempuran yang ada di Surabaya. Peristiwa BLA ini merupakan titik kulminasi dari berbagai pertempuran-pertempuran yang ada di Jawa Barat. Tapi peristiwanya sendiri bukan lah sebuah pertempuran bahkan dapat dikatakan kalau BLA ini adalah suatu pengorbanan yang benar benar dilaksankan secara tulus dan ikhlas. Memang terjadi pertempuran di tempat lain di Jawa Barat ini, jadi akibat kehilangan akal terutama dari pasukan sekutu karena tidak tau lagi caranya untuk menutupi kerugian mereka ini, karena mereka ditempatkan di Indonesia ini khususnya di Jawa Barat ini mereka awalnya bukan untuk bertempur tapi untuk menyelesaikan penyerahan tentara Jepang terhadap sekutu. Tapi ternyata mereka malah menghadapi kesulitan yang lebih dari perkiraan, dan pada intinya mereka tidak mengetahui gejala yang mereka belum mengetahuinya. Situasi kondisi di Indonesia sudah berubah dari Perang Dunia ke 1 dengan Perang Dunia ke 2 dimana kalau semangat warga Indonesia untuk merdeka sangatlah tinggi, karena sudah mengalami dua negara penjajah yang memang benar benar sangat menyedihkan ketika dijajah, apalagi oleh Jepang yang memang bener kejam. Tapi ada faedahnya dari sistem penjajahan yang kejam dari Jepang ini, yaitu meningkatkan semangat merdeka yang benar benar tertanam di hati masyarakat Indonesia, dijajah itu suatu penderitaan yang sangat luar biasa dan hasrat untuk merdeka dari sudah benar benar memuncak. Jadi ketika masih ada penekanan terhadap rakyat Indonesia sudah pasti dilawan sampai tentara sekutu tu dibegal dibeberapa tempat yang mula-mula di jalan kereta api di Purwakarta, di Tambun itu dibegal oleh kita. Habis barang-barang untuk perlengkapan mereka di Bandung dirajam untuk dipihak kita sebagai pemberontak pada waktu itu. Kemudian beralih lagi melalui kereta api tapi sekarang melewati jalan besar, Bogor, Sukabumi dan sebagainya. Tetapi itupun lebih rumit lagi karena disetiap daerah itu ada hambatanhambatan sampai kurang lebih konvoi 150 kendaraan itu sampai di Bandung itu sudah compang-camping. Barangkali pernah dengar peristiwa Bojongkokosan. Kemudian, Bojongkoksan itu daerah Sukabumi dan Bogor. Kemudian di Sukabumi terjadi pertempuranpertempuran walaupun dikita sedikit kurang. Walaupunsebetulnyabukan suatukekuatanseimbang antara kekuatan Inggris dengan pasukan gerilyagerilya kita. Pasukan Inggris konvoinya memakai tank-tank baja ya sedangkan dari atas juga memakai pesawat terbang. Tapi seperti yang saya katakan tadi bangsa Indonesia ingin merdeka itu sudah melakukan segala-galanya. Kemungkinan besar sudah tidak dipikirkan lagi. pokoknya kita merdeka. Nah, dari kesulitan-kesulitan dengan hambatanhambatan yang demikian, inggris itu sebagai pimpinan oleh tentara sekutu di Jawa Barat seperti kehabisan akal. Oleh karena itu terjadinya peristiwa Bandung Lautan Api berkaitan dengan kerugiankerugian dengan yang mereka derita sebelumnya. Kalau Bandung tidak diperbaiki secara keseluruhan karena di dalam saja demikian sulit sampai di dalam Bandung saja mulai dari pertempuran dengan para pejuang di Bandung. sampai waktu itu terbesit suatu omongan tiada hari tanpa pertempuran di Bandung ini. Satu brigade pasukan armed untuk tugas yang utama tadi menuju. Sebetuknya barangkali dengan tempat-tempat yang lain itu cukup satu agen saja

HISTORIA: Jurnal Pendidik dan Peneliti Sejarah, p-issn:2620-4789 | e-issn:2615-7993 
HISTORIA: Jurnal Pendidik dan Peneliti Sejarah, 3(2), 103-112. DOI: https://doi.org/10.17509/historia.v3i2.21607.

dari sekutu. Itu hanya menyelutui bekas tentara musuh dan mengembalikan pihaknya. Tidak perlu dengan didampingi oleh tentara yang cukup besar. Nah oleh karena itulah maka mereka menyusun kembali strategi yang lebih ampuh. Terutama situasi Bandung ini, situasi Bandung harus seluruhnya dikuasai oleh mereka, karena pada waktu itu yang baru bisa dilaksanakan Bandung hanya bisa dibagi dua Bandung Selatan dan Bandung Utara. Bandung selatan untuk pejuang, Bandung utara untuk tentaratentara sekutu dan sekutu tentara Belanda yang baru dikeluarkan dari interniran. Kemudian tentara Jepang yang masih bisa dipergunakan oleh mereka. Dengan cara demikian dibagi dalam demarkasi lain, bangun dibagi dua dari andir sampai ciroyom dengan garis demarkasi di jalan kereta api. Ini tindakan awal. Karena sebelum-sebelum dibagi dua itu perampokan-perampokan katakanlah bukan sebuah pertempuran besar-besaran, perampokan dari pihak gerilya kita terhadap tentara Inggris itu banyak sekali terjadi perampokan bersenjata sampai kepada diplomasi ala angkatan, bukan angkatan. Diplomasi yang dilakjukan oleh para pejuang kita yang disebut diplomosi you muslim, i muslim, teretet no! Tapi ini berhasil banyak ya jadi dengan demikian itu ada hubungan antara tentara-tentara yang muslim kita dengan mereka.

Pa Asep: ternyata mereka juga sebagai tentara juga muslim jadi begitu datang kesini yang dihadapi adalah pejuang muslim juga, jadi kalau ketemu diperbatasan itu you muslim, i muslim, you muslim, teretet no! Jangan-jangan-jangan tembak itu sebabnya you muslim, i muslim, you muslim, teretet no!. Jadi kita para pejuang banyak yang dibantu.

Pa Asep: Teretet no pa

Pa Tatang: teteretet

Pa Asep: itu kelemahan sekutu disitu karena banyak ternyata tentara sekutu itu orang India yang muslim. Datang kesini berhadapan dengan para pejuang yang agamanya muslim, jadi begitu mereka malah banyak senjata mereka yang dijebloskan dari rampasan Jepang itu sebagian dimasukkan dari gudang mereka sebagian dikasihken kepada para pejuang-pejuang muslim itu. Banyak itu luar biasa itu, mangga teraskeun.

Pa Tatang: disamping itu juga ada barangkali tidak pernah sebelumnya bahwa mereka yang ditempatkan di Indonesia terutama tentara-tentara itu loyo. Bayangkan saja setelah melakukan perang dunia 2 yang demikian besar dan demikian ganas. Mereka lagi, tentara India itu ditempatkan di mediteran yang paling ganas daerah pertempuran yang paling ganas.
Setelah itu ternyata bahwa sekutu yang menang. Demikian besar sekali, tempat asal mula mereka ke kampung-kampung mereka mendapat perintah harus ke Indonesia, dan di Indonesia mereka mendapat masalah yang hampir sama besarnya pada perang dunia waktu itu. Jadi mereka itu tentara yang sudah loyo, jadi diplomasi-diplomasi militer itu bisa terjadi ya you muslim, i muslim, you muslim, teretet no!. Lebih daripada itu akhirnya barter, kita butuh peluru mereka perlu makanan yang lain daripada makanan mereka sehari-hari, mereka ingin sekalikali membuat sate kambing. Dan tukar-menukar. Tukar peluru ditukar dengan kambing. Nah karena kekesalan inilah mungkin diadakan tindakan yang lain oleh tentara sekutu, sudah sekarang jangan Bandung dibagi dua saja tapi seluruh kekuatan ekstrimis, kekuatan pemberntak ini itu dikeluarkan dari Bandung. ini terjadi peoristiwa ini pada tanggal

Pa Lili: Peristiwa Bandung Lautan Api, peristiwa Bandung lautan api 24 Maret 46' itu bukan suatu peristiwa kepahlawanan, itu peristiwa yang menyedihkan, yang menyakitkan. Harus meninggalkan Bandung yang dicintai. Harus meninggalkan kekayaan, harus meninggalkan kota Bandung. kejadiannya itu diluar kemarahan kejengkelan para sekutu kepada Indonesia, karena kerugian yang menjadikan luar biasa oleh pertempuran Bojongkokosan sama dengan peristiwa di Bandung harus perang melawan banyak sekali ada perwiranya. Banyak sekali, peristiwa Bandung lautan apinya sendiri menyedihkan. Masyarakat yang berkorban meninggalkan kekayaannya, meninggalkan harus melaksanakan tugasnya meninggalkan peristiwa ini rasa kesetiaan kepada negara

Pa Asep: sehingga timbul pada waktu itu banyak para pengungsi ke selatan, ke utara, ke timur, ke barat. Ada satu lagu yang bapa sangat-sangat tidak mungkin dilupakan, antara lain: "Bandung Ibukota Priangan, tanah tumpah darahku kini telah jauh dimata, aku rindu padamu, marilah temanku seperjuangan, rebut Bandung Kembali" Itu didengungkan digununggunung karena orang Bandung sebetulnya sangat mencintai orang Bandung. namun karena perjuangan masyarakat harus meninggalkan kota Bandung ini mengungsi ke kampung-kampung pegunungan barat, timur, utara, selatan itu antara lain itu yang disampaikan guru-guru SMP saat itu karena smp pada saat itu sekolah tinggi lah kalau sekarang. Ya di Tasikmalaya itu tidak ada SMP, di Garut tidak ada, di Sumedang tidak ada hanya satu, di Tasik itu hanya ada sekolah pertanian, sekolah pertukangan, kalau

HISTORIA: Jurnal Pendidik dan Peneliti Sejarah, p-issn:2620-4789 | e-issn:2615-7993 
mau SMP harus ke Garut, harus ke Bandung. Kalau mau masuk SMP harus ujian tugas, bapa waktu itu SMP waktu itu kelas dua tapi sudah masuk Tentara Republik Indonesia atau disebut juga Tentara Pelajar di mana disitu ada SMP, kompi-kompi pelajar di Garut ada Kompi, di Tasik ada Kompi, kompi pelajar Tasik di Sumedang tidak ada karena di Sumedang tidak ada SMP ya tidak seperti sekarang, sekarang tu mungkin sampai ada dua dulu ga ada namanya pada waktu itu SMP itu syugako kalau SD itu kokumingako ya kalau sekolah tinggi itu daidako itu bahasa Jepang. Tapi pada waktu proklamasi pemuda-pemuda ini dikumpulkan kelas 2 keatas ayo latihan walaupun pada zaman Jepang pun kita sudah dilatih tiap-tiap SD saja waktu itu kokumingako sekolah dasar pagipagi dibentuk pasukan ada pleton, ada kompi ada batalyon, istilahnya kalau perguru itu guntaico kalau seksi atau pleton itu sotai jadi sotaico. jadi tiap pagi itu kumpul, laporan, kalau dulu daisotai sotaicoika ninjuhasue ninjamas itu selalu tiap sekolah ada begitu tai-tai icisota nicuhasume icomas itu sama dengan sekarang, pleton dua kekuatan 27 orang siap itu icomas susosai artinya. Ya silahken pa terusken pa

Pa Tatang: barangkali lebih mendasar saja ya saya ingin memberikan dasar saja. tadi sudah saya sampaikan bahwa setelah Perang Dunia ke II, sutet situasi kondisi Bangsa Indonesia ini ya terutama tumbuhnya hasrat untuk merdeka gituya, sekalipun penderitaan, sekalipun pengalaman yang diberikan oleh Jepang waktu dijajah itu ya merupakan sesuatu yang sangat menyedihkan, sangat mengerikan karena lain sekali dijajah Belanda lain dijajah Jepang. Dijajah Belanda itu pelan-pelan kita dihisap kalau di jajah Jepang kita itu dirampok segala-galanya, dirampok segalagalanya. Terutama segala sesuatu yang mereka bisa gunakan untuk menunjang peperangan mereka di Asia Timur Raya ini, jadi semacam bahan makanan, bahan pakaian dan sebagainya habis terkuras nah inilah yang membuat kita menjadi bangsa yang lebih kuat dengan tempaan-tempaan ini.

Pa Asep: mohon maaf sedikit, zaman Jepang itu setiap petani itu ada kewajiban untuk menyerahkan hasil pertanian untuk tentara Jepang, istilahnya deovera waktu itu jadi 10\% dari penghasilan petani harus diserahkan untuk peperangan timur raya, petani pun diperas, hasil pertanian 10\% harus disetorkan kepada kepentingan Jepang untuk peperangan Asia Timur Raya padahal luar biasa mereka itu rel-rel kereta api Tasik dicabut itu rel-relnya dibabad, eh ini Bandung sampai Ciwidey itu dihentikan dicabut, dibawa oleh Jepang. Segala macam yang bisa digunakan mereka diangkut. Di Garut itu ada alun-alun disekelilingnya pake besi, bagus sekali oleh Jepang dicabut, dibawa besi-besinya itu jadi jangan sangat berguna, itu juga ada besi-besi bagi kita keindahan diangkut oleh mereka jadi luar biasa Jepang itu keganasan itu walaupun disamping itu yang memberikan semangat kita ketika Belajar menembak, itu Jepang yang mengajarkan dibentuk tentara PETA, Pembela Tanah Air. Dibentuk Heihon, Heiho itu Bangsa kita yang diperbantukkan pada tentara Jepang Heiho itu namanya. Kalau PETA itu Pembela Tanah Air sukarela itu dibentuk oleh Jepang atas usulan pa Gatot Mangkuperaja salah seorang pemuda orang sunda saat itu Jepang untuk membentuk tentara Pembela Tanah Air padahal pa Gatot Mangkupraja itu ada maksud lain supaya bangsa kita bisa nembak untuk dipersiapkan nanti revolusi pada saat proklamasi luar biasa pa Gatot Mangkuperaja itu., nah silahken.

Pa Tatang: penderitaan yang luar biasa ini, inilah yang membangkitkan semangat kita ya untuk menjadi bangsa yang merdeka baik diwaktu jaman Belanda hanya dihisap saja, lebih lagi setelah dijajah Jepang dirampok ya inilah yang membikin kita menjadi Bangsa yang lebih matang memikirkan nasibnya sendiri. Bahwa kita tidak mungkin terus menerus menjadi isapan Bangsa-Bangsa yang laen, bagaimanapun saya kira tidak ada penjajahan yang mempunyai tujuan lain daripada menghisap. Baik menghisap baik-baik ataupun dengan cara merampok walaupun Indonesia menjadi lebih matang diatas kaki sendiri sehingga diwaktu itu harapan kita begitu pihak Jepang kalah disitu kebulatan tekad Bangsa Indonesia meledak jadi tidak ada jalan lain setelah Jepang menyerah pada tentara sekutu. Maka kesempatan itu jalan baik bagi kita untuk menyerahkan kemerdekaan. Untungnya waktu terakhir kita dijajah Jepang itu sempat Jepang itu untuk mengeloni kita supaya kita rela terus untuk dihisap oleh mereka nah itu dininabobokan dengan memberikan memberikan apa namanya jani-janji untuk dimerdekakakan bagi Bangsa Indonesia yang sudah sangat rindu dengan kemedekaan itu ini langsung di anu di apa secara diaktifkan itu dilaksanakan sampai pada waktu itulah kita memulai apa yang dinamakan Panitia Persiapan Kemerdekaan Indonesia jadi sudah ada satu tujuan tertentu kalau Jepang tidak jadi juga memerdekakan kita misalnya juga menderita kekalahan tapi kita sudah mempunyai landasan untuk memulai hidup baru sebagai bangsa yang merdeka ini oleh karena itu kesempatan ini betul-betul dipergunakan untuk 
HISTORIA: Jurnal Pendidik dan Peneliti Sejarah, 3(2), 103-112. DOI: https://doi.org/10.17509/historia.v3i2.21607.

mempersiapkan kemerdekaan Indonesia. kebetulan Jepang yang kalah dan kesempatan ini betul-betul kita pergunakan sebaik-baiknya walaupun waktu itu ada sedikit perbdeaan pendapat antara para pemuda dan angkatan tua. Angkatan tua itu masih mengharapkan kemerdekaan diberikan oleh Jepang tapi angkatan mudanya itu sama sekali tidak mengharapkan kemerdekaan diberikan oleh siapapun tapi kita sendiri yang harus merebutnya sampai Bung Karno dan Bung Hatta mau tidak mau mengikuti anjuran daripada pemuda itu. Terlebih lagi secara jelas mengetahui kekuasaan Jepang sudah betul-betul runtuh walaupun angkatan perangnya masih-masih apa namanya masih eksis ya seperti di Jakarta atau di daerah lain juga sampai-sampai waktu kita mau apa namanya mengkonsepkan proklamasi itupun ya itu ya pasti dibawah kekuasaan Jepang. Hanya untung diantara sekian banyak orang-orang Jepang yang itu ada yang mempunyai mempunyai ide yang yang lebih mulia. Itu Laksamana Maeda panglima angkatan laut di Indonesia terutama di Jawa pada waktu itu kita dilindungi oleh Laksamana Maeda ini sampai para proklamator itu mengkonsep proklamasi kemerdekaan itu dirumahnya Laksamana Maeda karena Jepang itu masih berkuasa di seluruh wilayah Jakarta hanya dirumah Maeda itu bebas karena tidak dijaga oleh Angkatan Darat. Beliaukan panglima Angkatan Laut jadi punya ekstra teritorial, nah ini begitu prokalamsi kemerdekaan diumumkan sedikit banyaknya bagi para pemuda itu sudah punya persiapan. Persiapan pertama yang disampaikan oleh pa Asep tadi waktu kita sekolah di jaman Jepang itu kita sudah dididik kemiliteran. Maksudnya waktu itu untuk membantu tentara Jepang. Dari Sd sampai sekolah lanjutan itu dalam 3 hari 1 minggu itu ada latihan tentaranya bagus sekolah betul-betul barangkali satu minggu itu paling produktif itu 1 hari lah. Yang lainnya itu, latihan ketentaraan dan kinrohosi itu kerja bakti kita sebagai anak-anak sekolah itu, itu harus mengenal terimakasih juga pada tentara Jepang ikut membersihkan instalasiinstalasi militer mereka. Kita diangkut ke pangkalan Husein bersih-bersih disana atau kepangkalan atau ke asrama lainnya ikut juga kinrohosi namanya terjadi kerjabakti. Nah diam-diam ya dalam situasi yang demikian itu pelajar-pelajar juga mulai sadar harus ada ikatan-ikatan oleh karena itu, mulai sadar harus ada ikatan-ikatan sekolah menengah keatas, di Bandung ada banyak. Ada ISLB (Ikatan Sekolah Lanjutan Bandung), GASEWA (Gabungan Sekolah Menengah, dan gabungan sekolah teknik.
Akhirnya semua itu dikoordinir oleh kakak tingkat saya, menjadi suatu ikatan yang lebih tinggi yaitu Ikatan Pelajar Indonesia (IPI), demikian terjadi pemberontakan di Bandung, ini lah yang paling berjasa untuk menyatukan masyarakat terutama pelajar-pelajar di Bandung, seperti Pak Lili dan saya dulunya ada di IPI Bandung, kemudian setelah menginjak masa perjuangan, pelajar-pelajar nya hilang tapi organisasi-organisasi nya tetap anggota nya menjadi pejuang-pejuang, orientasi untuk belajar hilang tapi berubah menjadi pejuang pejuang. Maka ini lah awal kekuatan pejuang yang ada di Bandung yang direkrut oleh tentara Jepang menjadi Peta yaitu tentara yg sukarela, jadi di Bandung ini ada dua kekuatan yaitu pemuda dan satu nya lagi yaitu kekuatan yang sudah dipersiapkan menjadi tentara yaitu PETA, dan kedua kekuatan inilah yang menjadi kekuatan pejuang di Bandung. Itu menjadi organisir pemuda semacam TRI, Tritaha, ada yang di Kereta Api, yang di Posdad telpon, dan mereka yang menjadi pasukan Hizbullah, dan itu menjadi awal mula terbentuk nya BKR (Badan Keamanan Rakyat), bukan lagi pejuang berbeda dengan $B K R$ yang resmi dari pemerintah tapi tujuan nya satu yaitu kemerdekaan Indonesia, nah dari BKR berubah menjadi TKR (Tentara Keamanan Rakyat) dan akhirnya menjadi TNI (Tentara Nasional Indonesia).

\section{SIMPULAN}

Dalam sejarah lisan tidak semata-mata ditujukan kepada para tokoh, tetapi juga memberikan kesempatan kepada setiap orang yang dianggap penting untuk di wawancarai agar tergali informasinya. Sumber sejarah lisan yang ditinggalkan dalam penelitian sejarah akan musnah secara perlahan dan sedikit demi sedikit dan akhirnya benar-benar lenyap seiring dengan tadanya para saksi sejarah. Di masa mendatang dokumen-dokumen akan jarang diproduksi karena orang menyimpan data dalam komputer dan sejenisnya. Hasil penelitian berupa rekaman yang disimpan dalam pita kaset/CD merupakan upaya Departemen Pendidikan Sejarah dalam usaha penyelamatan, sedangkan penggunaannya merupakan hal kedua yang diserahkan kepada para peneliti dibidang ilmu yang bersangkutan. Departemen Pendidikan Sejarah akan melakukan wawancara secara intensif agar suara-suara masa lampau itu didokumentasikan dalam bentuk teks transkripsi. Transkripsi suara itu penting karena begitu suara diucapkan, maka yang tinggal adalah kesenyapan. Dimulai dari perekaman dan dilanjutkan dengan pengolahan menuju transkripsi yang akhirnya akan berubah bentuknya menjadi dokumen. 
Kerja sejarah lisan berpacu melawan waktu dari usia orang yang akan diwawancari, sementara banyak keterangan penting yang masih mengendap dalam ingatan para pelaku sejarah yang belum diungkap. Berikutnya adanya keterbatas dana dan sarana, maka prioritas objek wawancara diberikan kepada para tokoh tertentu tanpa mengurangi arti penting segi-segi yang mencerminkan suasana kehidupan kemasyarakatan. Selain itu juga mengingat bahwa kegunaannya yang sangat besar dalam pengembangan ilmu pengetahuan maka diharapkan adanya berbagai usaha untuk terus menggalakkan kegiatan sejarah lisan ini semacam penelitian yang akan dilakukan. Tugas sejarah lisan sebetulnya dapat dilakukan oleh orang-orang dari segala lapisan asal dengan cara yang tepat dan cermat.

\section{REFERENSI}

Aharon, E.B. (2020): Doing oral history with the Israeli eliteand the question of methodology in International Relations Research, The Oral History Review, 47(1), 3-25. 10.1080/00940798.2019.1702467

ANRI (1981), Lembaran berita sejarah lisan. Jakarta: Arsip Nasional RI.

Departemen Pendidikan Sejarah UPI (2019). Arsip, Skripsi/ Karya Ilmiah Mahasiswa S1 Periode tahun 2010-2019. Bandung: Depatemen Pendidikan Sejarah UPI.

Garraghan, G J (1957). A guide to historical method. New York: Fordham University Press.
Hammond, A. (2015). Through a glass, darkly: the CIA and oral history. History: The Journal of the Historical Association, 100(340), 313-14.

Harding, J \& Gabriel, J. (2004). Communities in the making: pedagogic explorations using oral history. International Studies in Sociology of Education, 14(3).

Holmes, K; Thomson, A; Darian-Smith, K \& Edmonds, P. (2016). Oral history and australian generations, Australian Historical Studies, 47(1), 1-7. 10.1080/1031461X.2016.1119778

Kochhar, S. K (2008). Pembelajaran sejarah. Diterjemahkan oleh Purwanta dan Yovita Hardiwati. Jakarta: Grasindo

Kuntowijoyo (2003). Metodologi sejarah. Yogyakarta: Tiara Wacana

Priyadi, S (2017). Sejarah lisan. Yogyakarta: Penerbit Ombak

Rogan, E. (2007). The palestine police oral history project: the middle east centre, St antony's college, university of oxford, Bulletin for the Council for British Research in the Levant, 2(1), 35-40.

Sjamsuddin, H. (2012). Metodologi sejarah. Yogyakarta: Ombak.

Narasumber

1. Kolonel (Purnawirawan) Lili Somantri (93 tahun)

2. Kolonel (Purnawirawan) Tatang Endang (94 tahun)

3. Kolonel (Purnawirawan) Asep (92 tahun) 